\title{
Development of minapolitan area in Bitung City, Indonesia
}

\author{
Pengembangan Kawasan Minapolitan di Kota Bitung, Indonesia \\ Hernie Onibala $^{1 *}$, Rene Charles Kepel ${ }^{2}$, and Hengky J. Sinjal ${ }^{1}$ \\ ${ }^{1}$ Program Studi Ilmu Perairan, Program Pascasarjana Universitas Sam Ratulangi. Jl. Kampus Unsrat Kleak, \\ Manado 95115, Sulawesi Utara, Indonesia \\ ${ }^{2}$ Fakultas Perikanan dan Ilmu Kelautan, Universitas Sam Ratulangi. Jl. Kampus Unsrat Bahu, Manado 95115, \\ Sulawesi Utara, Indonesia \\ *E-mail: hernieonibala@gmail.com
}

\begin{abstract}
The Ministry of Maritime Affairs and Fisheries has set Bitung City as one of the locations for minapolitan program implementations based capture fisheries. Minapolitan's fisheries Bitung City is a neighborhood-based economic development fishing effort developed in an integrated manner by the government, the private sector and community to create a business climate for better for regional economic growth, job creation and community income neighborhood Bitung City. This study aims to analyze the policy strategy for developingMinapolitan Region of the City of Bitung through SWOT analysis and determine priorities for the development strategy of Bitung city Minapolitan Region. The research method is a survey study, data were collected through interviews and direct observation and literature. SWOT analysis is used to identify strengths, weaknesses, opportunities and threats. Furthermore, to determine the alternative development strategy used OSPM. The study concluded that the strategies that can be used for the development Minapolitan in Bitung are as follows: 1) optimization of fisheries production; 2) improve the facilities, infrastructure and transport infrastructure and fishing port; 3 ) by improving the quality of human resources in fishing; 4) improving the quality of fisheries products to be able to compete in free market; 5) to build the collective awareness to stay remain committed and consistent in developing minapolitan; 6) industrialization of fisheries bu supporting Special Economic Zone (SEZ).
\end{abstract}

Keywords: minapolitan; fishery production; capture fisheries; Bitung; Indonesia.

Abstrak: Kementerian Kelautan dan Perikanan telah menetapkan Kota Bitung sebagai salah satu lokasi implementasi program minapolitan berbasis perikanan tangkap. Kawasan minapolitan perikanan tangkap di Kota Bitung adalah suatu kawasan pengembangan ekonomi berbasis usaha penangkapan ikan yang dikembangkan secara terintegrasi oleh pemerintah, swasta dan masyarakat untuk menciptakan iklim usaha yang lebih baik untuk pertumbuhan ekonomi wilayah, penciptaan lapangan kerja dan pendapatan masyarakat kawasan Kota Bitung. Penelitian ini bertujuan menganalisis strategi kebijakan pengembangan Kawasan Minapolitan kota Bitung melalui analisis SWOT dan menetapkan prioritas strategi pengembangan Kawasan Minapolitan kota Bitung. Metode penelitian adalah penelitian survei, data dikumpulkan melalui wawancara dan observasi langsung dan literatur. Analisis SWOT digunakan untuk menidentifikasi kekuatan, kelemahan, peluang dan ancaman. Selanjutnya untuk menentukan alternatif strategi pengembangan digunakan OSPM. Hasil penelitian menyimpulkan bahwa strategi yang dapat digunakan untuk pengembangan minapolitan di Bitung sebagai berikut: 1) optimalisasi produksi perikanan; 2) meningkatkan sarana, prasarana dan infrastruktur transportasi dan pelabuhan perikanan; 3) peningkatan kualitas SDM nelayan; 4) peningkatan kualitas produk perikanan untuk dapat berdaya saing dipasar bebas; 5) membangun kesadaran kolektif tetap komitmen dan konsisten dalam mengembangkan minapolitan; 6) industrialisasi perikanan dengan mensuport KEK.

Kata-kata kunci: Minapolitan; produksi perikanan; perikanan tangkap; Bitung; Indonesia.

\section{PENDAHULUAN}

Dalam rangka memanfaatkan potensi sumber daya alam yang ada di Kota Bitung, khususnya yang terkait dengan pengelolaan hasil laut dan perikanan, maka diupayakan suatu pendekatan melalui produk, yaitu perencanaan pengembangan kawasan perikanan berupa Minapolitan. Perencanaan pengembangan kawasan minapolitan merupakan suatu upaya untuk memanfaatkan lahan serta potensi yang ada dalarn mengatasi permasalahan yang dihadapi dalam pengelolaan dan penataan ruang untuk kegiatan yang memanfaatkan hasil perikanan yang melimpah di (KKP, 2011).

Kawasan Minapolitan Kota Bitung adalah salah satu kawasan pengembangan Minapolitan berbasis perikanan tangkap dari beberapa kawasan minapolitan di Indonesia, yang ditetapkan melalui 
SK Menteri Kelautan dan Perikanan Nomor: KEP.32/MEN/2010 (Kepmen, 2010) dan ditindaklanjuti oleh Surat Keputusan Walikota Bitung (Nomor: 130, Tahun 2010) dengan menetapkan Kawasan Minapolitan Kota Bitung, yang meliputi Kecamatan Aertembaga, Kec. Lembeh Selatan, dan Kec. Lembeh Utara, dengan basis area Pelabuhan Perikanan Samudera Bitung (Skep Bitung, 2010). Kota Bitung, dengan segala potensi yang ada, berusaha untuk memacu perekonomian dengan memanfaatkan secara optimal potensi yang telah ada. Dengan karakter baharinya, aktivitas ekonomi di Kota Bitung didominasi oleh aktivitas yang berhubungan dengan kelautan. Dengan demikian, dapat dikatakan, bahwa keberadaan laut di Bitung merupakan potensi yang berharga bagi perekonomian.

Program Minapolitan di Kota Bitung telah dilaksanakan sejak tahun 2010, namun dalam pelaksanaannya belum menunjukkan hasil yang diharapkan sesuai dengan tujuannya. Kondisi yang ada saat ini, di zona inti kawasan, adalah Pelabuhan Perikanan Samudera Bitung dan kelengkapan lainnya, seperti fasilitas pokok, funsional dan penunjang. Keberadaan akan seluruh fasilitas ini sangat menunjang keberlangsungan akan kegiatan minapolitan; hanya saja, dalam beberapa segi pelayanan dinilai masih kurang terutama dalam hal peningkatan produksi hasil tangkapan yang belum bisa memenuhi kebutuhan bahan baku untuk industri perikanan terutama industri pengolahan hasil laut di Kota Bitung. Maju mundurnya industri perikanan, khususnya pengolahan hasil laut, sangat bergantung pada kecukupan bahan baku yang tersedia untuk menggerakkan perindustrian di Kota Bitung yang merupakan Kawasan Ekonomi Khusus (KEK) berbasis industri. Masalah lainya adalah terbatasnya modal dan teknologi penangkapan ikan, rendahnya kualitas SDM nelayan, lemahnya pengawasan, dan data statistik perikanan tangkap yang kurang akurat, sehingga kenyataannya dibutuhkan persiapan dan pembenahan yang menyeluruh.

Dalam rangka pengembangan industri yang ada di KEK Bitung ini, khususnya pengembangan industri pengolahan hasil laut (perikanan), maka salah satu upaya yang dilakukan adalah menyediakan bahan baku sesuai dengan kebutuhan industri tersebut. Salah satu sumber penting untuk memasok bahan baku dalam menggerakkan industri tersebut yaitu Kawasan Minapolitan yang ada Kota Bitung.

Implementasi kebijakan pengelolaan sumber daya perikanan melalui program minapolitan di Kota Bitung akan dapat terlaksana secara menyeluruh dan berimplikasi positif bagi masyarakat bilamana kinerja aparat pemerintah dapat diterapkan secara optimal serta penerimaan masyarakat yang baik atas kebijakan pengelolaan tersebut. Karakteristik perikanan tangkap dan industri pengolahan hasil laut, yang bersifat common property dan open accses, sektor ini dinilai rawan penyimpangan terhadap implementasi program minapolitan. Oleh karena itu, implementasi dari program ini perlu dievaluasi untuk mencegah kegagalan program, dan hasil evaluasi diharapkan mampu memberikan kontirbusi pemikiran untuk dikembangkan dalam mendukung kawasan ekonomi khusus (KEK) di Kota Bitung.

Penelitian ini bertujuan untuk menganalisis strategi kebijakan pengembangan Kawasan Minapolitan Kota Bitung menggunakan Analisis SWOT (Strenght, Weaknesess, Oportunity, Threat) dan menetapkan prioritas strategi pengembangan Kawasan Minapolitan kota Bitung

\section{MATERIAL DAN METODA}

Penelitian ini mengggunakan metode deskriptif; dilakukan di Kota Bitung, Sulawesi Utara. Metode pengumpulan data yang digunakan didasarkan pada jenis data yang dibutuhkan. Data primer diperoleh melalui observasi, wawancara mendalam, kuisioner dan dokumentasi; sedangkan data sekunder diperoleh melalui studi kepustakaan atau studi literatur yang relevan atau berkaitan dengan rumusan masalah, serta mengambil data-data yang dapat diperoleh dari berbagai sumber, baik melalui cara instansional maupun melalui cara pengumpulan dokumen-dokumen yang dapat mendukung penelitian ini. Pengolahan data dilakukan dengan menggunakan Analisis SWOT. Analisis SWOT merupakan model analisis untuk membandingkan faktor eksternal berupa peluang dan ancaman dengan faktor internal berupa kekuatan dan kelemahan (Rangkuti, 2008). Analisis SWOT digunakan untuk menentukan strategi pengembangan kawasan minapolitan; dan untuk menentukan stretegi alternatif digunakan analisis QSPM.

Rumusan strategi pengelolaan dan pengem-bangan minapolitan di Kota Bitung dilakukan melalui penelaahan kondisi internal dan eksternal. Kondisi internal dan eksternal tersebut selan-jutnya menjadi komponen-komponen data analisis SWOT.

Kuesioner mengenai faktor Internal dan Eksternal ini disebarkan kepada stakeholder untuk mengetahui mana yang termasuk kekuatan (strengths) dan kelemahan (weaknesses) dalam faktor Internal serta peluang (opportunities) dan ancaman (threaths) 


\begin{tabular}{|c|c|c|}
\hline EFAS & $\begin{array}{l}\text { KEKUATAN/STRENGT (S) } \\
\text { - Jumlah kapal penangkap ikan } \\
\text { - Ketersediaan sumberdaya ikan } \\
\text { yang cukup } \\
\text { - Jumlah industri pengolahan dan } \\
\text { penangkapan ikan } \\
\text { - Keberadaan PPS Bitung yang } \\
\text { berskala internasional } \\
\text { - } \text { Komitmen kuat dari PEMDA }\end{array}$ & $\begin{array}{l}\text { KELEMAHAN/WEAKNESS }(\mathbf{W}) \\
\text { - Upaya peningkatan kapasitas } \\
\text { nelayan kurang optimal } \\
\text { - Koordinasi antar kelembagaan } \\
\text { terkait belum optimal } \\
\text { - Infrastruktur belum memadai } \\
\text { - Inkonsistensi anggaran } \\
\text { pengembangan minapolitan } \\
\text { - Tingkat pendidikan nelayan yang } \\
\text { masih rendah }\end{array}$ \\
\hline $\begin{array}{l}\text { PELUANG/OPPORTUNITY (O) } \\
\text { - Tingginya permintaan ikan } \\
\text { - Adanya lembaga pengembangan } \\
\text { SDM perikanan } \\
\text { - Adanya Kawasan Ekonomi Khusus } \\
\text { (KEK) } \\
\text { - Akses transportasi dan } \\
\text { telekomunikasi } \\
\text { - Lokasi Daerah Penangkapan Ikan }\end{array}$ & \begin{tabular}{l}
\multicolumn{1}{c}{ STRATEGI - SO } \\
- Optimalisasi produksi ikan \\
- Meningkatkan sarana, prasarana \\
dan infrastruktur transportasi dan \\
pelabuhan perikanan
\end{tabular} & \begin{tabular}{l}
\multicolumn{1}{c}{ STRATEGI - WO } \\
- Kerja sama kemitraan bisnis \\
minapolitan \\
- Peningkatan kinerja pengelola \\
pelabuhan perikanan \\
- Industrialisasi perikanan dengan \\
mensuport KEK \\
- Peningkatan kualitas SDM nelayan \\
untuk melakukan kegiatan \\
penangkapan ikan
\end{tabular} \\
\hline $\begin{array}{l}\text { ANCAMAN/TREATH }(\mathbf{T}) \\
\text { - Kelestarian sumberdaya ikan } \\
\text { terganggu } \\
\text { - Terjadinya IUU fishing } \\
\text { - Stabilitas politik nasional yang } \\
\text { labil } \\
\text { - Aglomerasi Perekonomian Global } \\
\text { dan Regional } \\
\text { - Cuaca yang tidak menentu }\end{array}$ & $\begin{array}{l}\text { STRATEGI - ST } \\
\text { - Pengembangan perikanan tangkap } \\
\text { berkelanjutan } \\
\text { - Pengembangan pola kemitraan } \\
\text { antara nelayan, pemilik kapal dan } \\
\text { eksportir yang berimbang } \\
\text { Peningkatan kualitas produk } \\
\text { perikanan untuk dapat berdaya } \\
\text { saing dipasar bebas }\end{array}$ & $\begin{array}{l}\quad \text { STRATEGI - WT } \\
\text { - Penambahan jumlah SDM aparatur } \\
\text { pelabuhan untuk pengendalian IUU } \\
\text { fishing di pelabuhan perikanan } \\
\text { - Strategi penambahan jumlah SDM } \\
\text { aparatur pelabuhan untuk } \\
\text { pengendalian IUU fishing. }\end{array}$ \\
\hline
\end{tabular}

Gambar 1. Matrik SWOT strategi pengembangan minapolitan perikanan tangkap di Kota Bitung

dalam faktor Eksternal. Gambaran kondisi internal dan eksternal di Kota Bitung didasarkan pada hasil pengamatan, kuesioner dan wawancara langsung dengan pihak-pihak terkait.

Berdasarkan hasil identifikasi isu dan masalah, didukung dengan berbagai data dan informasi yang telah dikumpulkan, selanjutnya dilakukan analisis SWOT. Berbagai data dan informasi yang bersumber dari isu-isu strategis sebagaimana telah dijelaskan di depan, selanjutnya diidentifikasi dan dikelompokkan untuk kemudian dimasukkan ke dalam tabel analisis SWOT.

\section{HASIL DAN PEMBAHASAN}

\section{Kedaaan Umum Kota Bitung}

Secara geografis Kota Bitung terletak di antara $1^{\circ} 23^{\prime} 23^{\prime \prime}-1^{\circ} 35^{\prime} 39^{\prime \prime}$ LU dan 125 $1^{\prime} 43^{\prime \prime}$ $125^{\circ} 18^{\prime} 13^{\prime \prime}$ BT dengan luas wilayah sebesar 304,00 $\mathrm{km} 2$. Jumlah penduduk Kota Bitung sampai pada tahun 2014 sebesar 214.932 jiwa. Di kota Bitung terdapat 4 pelabuhan, yaitu Pelabuhan Perikanan Samudra (PPS), Pelabuhan Feri, Pelabuhan
Kontainer, dan Pelabuhan Penumpang antar provinsi. Selain itu, ada juga pelabuhan kecil yang menghubungkan penduduk Pulau Lembeh dengan masyarakat Kota Bitung yang berada di Pulau Sulawesi. Pelabuhan Perikanan Samudra (PPS) merupakan tempat bersandarnya kapal-kapal perikanan sehingga di dalam PPS terdapat TPI (Tempat Pelelangan Ikan). Menurut jenis ikan, di Kota Bitung (tahun 2014) terdapat sekitar 50 jenis. Dari semua jenis ikan yang terdapat di kota Bitung, produksinya paling tinggi adalah ikan cakalang, karena produksinya paling banyak sehingga nilainya pun paling tinggi. Nomor dua setelah cakalang adalah madidihang atau sering juga disebut ikan tuna; jenis ikan ini juga produksinya kedua terbesar sesudah cakalang dan mempunyai nilai yang sangat tinggi bila di ekspor.

Produksi perikanan laut (tahun 2014) meningkat sebesar $0,09 \%$, yakni dari $146.940,4$ ton menjadi $147.069,8$ ton. Seiring dengan kenaikan produksinya, nilai produksi perikanan laut pada tahun 2014 juga mengalami peningkatan cukup signifikan, yaitu sebesar 39.23\%, yakni dari 1.214,96 milyar rupiah pada tahun 2013 menjadi 
1.691,58 milyar rupiah tahun 2014. Terdapat beberapa kelompok jenis ikan yang didaratkan di PPS Bitung, di antaranya, kelompok pelagis kecil, pelagis besar, dan demersal. Jumlah produksi bulanan dan tahunan berubah-ubah bergantung pada musim ikan, jumlah armada penangkapan yang melakukan operasi penangkapan, dan jumlah tripnya. Jumlah produksi ikan di PPS Bitung mencapai $111.315,130$ ton pada tahun 2014. Jenis ikan hasil tangkapan didaratkan selama 10 tahun terakhir (2005-2014) didominasi oleh jenis ikan cakalang (Katsuwonus pelamis), layang (Decapterus russelli), tuna (Thunnus spp.), dan tongkol (Euthynnus affinis). Jenis ikan yang memiliki volume produksi tertinggi pada periode tersebut adalah cakalang.

\section{Strategi Pengembangan Minapolitan}

Berikut ini adalah formulasi strategi dalam mengembangkan kegiatan Mina Politan di Kota Bitung, berdasarkan faktor internal dan eksternal (Gambar 1).

\section{Optimalisasi produksi ikan}

Strategi ini dimaksudkan untuk meningkatkan daya saing produk ikan khususnya tuna dan cakalang. Peningkatan daya saing tidak sematamata hanya mementingkan peningkatan produksi ikan tetapi lebih kepada peningkatan kualitas dan keberlanjutan sumberdaya ikan di masa mendatang

Strategi optimalisasi produk dalam kaitannya dengan kualitas adalah strategi untuk meningkatkan prosentase jumlah produk tuna dan cakalang kualitas I. Kualitas produk tuna dan cakalang sangat erat hubungannya dengan proses penanganan hasil tanggapan ikan di atas kapal hingga proses distribusi ke konsumen akhir. Aspek penting yang harus dipahami oleh pelaku usaha adalah 1) teknologi penanganan hasil tangkapan di atas kapal, 2) efisiensi alur distribusi produk, dan 3) inovasi teknologi distribusi produk. Strategi optimalisasi produk dalam kaitannya dengan peningkatan produksi dan menjaga keberlanjutan sumberdaya adalah bagaimana membuat kajian optimalisasi alokasi unit alat tangkap tuna dan cakalang di PPS Bitung.

\section{Meningkatkan sarana, prasarana, dan infrastruk- tur transportasi dan pelabuhan perikanan}

Strategi ini ditempuh untuk memberikan kenyamanan fasilitas pelayanan bagi pelaku usaha eksisting maupun pelaku usaha baru yang akan berinvestasi di kawasan industri PPS Bitung. Setidaknya ada tiga hal pokok yang harus diperhatikan yaitu jalur transportasi (darat, laut dan udara), teknologi informasi, fasilitas pelabuhan perikanan. Ketiga jenis infrastruktur tersebut merupakan elemen penting untuk mendukung pengembangan industrialisasi perikanan yang modern sehingga jenis, kapasitas dan kualitas fasilitas harus ditingkatkan sesuai dengan kebutuhan pengguna. Strategi ini dilakukan dengan menggunakan beberapa kekuatan internal sistem minapolitan di PPS Bitung untuk memanfaatkan beberapa peluang.

\section{Kerja sama kemitraan bisnis minapolitan}

Strategi ini harus konsisten dan kontinyu dilakukan oleh pihak pemerintah pusat maupun daerah. Kemitraan bisnis tidak hanya untuk menarik investor baru di kawasan industri PPS Bitung (zona inti) tetapi juga untuk daerah di sekitarnya (kawasan penunjang). Oleh karena itu, business plan zona inti dan zona penunjang harus dikemas menjadi lebih menarik, elegan, dan scientific sehingga dapat menjadi perhatian berbagai pihak khususnya pemerintah, dunia usaha, akademisi, masyarakat dan lembaga sosial lainnya. Dalam perspektif industri, kemitraan bisnis minapolitan identik dengan pengembangan kemitraan industri perikanan dimana secara fisik lokasi pengembangannya berada di kawasan ekonomi khusus (KEK). strategi ini dilakukan dengan harapan dapat mengurangi beberapa kelemahan internal sistem minapolitan di PPS Bitung sehingga dapat memanfaatkan beberapa peluang.

\section{Peningkatan kinerja pengelola pelabuhan perikanan}

Strategi ini merupakan upaya untuk meningkatkan kapasitas sumberdaya pengelola pelabuhan perikanan sehingga peran penting PPS Bitung dalam menunjang efisiensi usaha perikanan tangkap dapat dijalankan seoptimal mungkin. Dengan kata lain, pengelola pelabuhan perikanan dalam menjalankan kewajibannya harus dapat memberikan pelayanan terbaik agar kinerja pelabuhan perikanan tetap dapat berfungsi secara optimal dalam melayani industri perikanan.

Peningkatan kapasitas (capacity building) bagi pengelola pelabuhan perikanan didefinisikan sebagai "sampai seberapa jauh staf mampu menunjukkan kontribusi yang nyata terhadap pengembangan personal, organisasi dan masyarakat nelayan. Selain peningkatan kapasitas SDM pengelola pelabuhan, juga sangat penting untuk meningkatkan kapasitas lembaga pengelola pelabuhan. Pengembangan kelembagaan pelabuhan perikanan merupakan strategi dan cara untuk memulihkan, memperbaiki dan meningkatkan 
sinkronisasi hubungan kerja dalam kelembagaan pelabuhan perikanan sehingga meningkat prestasinya. Peningkatan kapasitas kelembagaan diarahkan kepada mengubah cara berpikir, sikap dan kebiasaan lama yang telah berurat akar dan memberikan wawasan baru atau nilai-nilai baru good governance.

\section{Industrialisasi perikanan dengan mensuport KEK} Industrialisasi perikanan pada dasarnya merupakan aktualisasi dari pengembangan pelabuhan perikanan. Pengembangan kapasitas, kualitas dan jenis fasilitas pelabuhan perikanan akan mendorong kegiatan ekonomi lainnya sehingga pelabuhan perikanan menjadi suatu kawasan pengembangan industri perikanan. Selain itu pembangunan Kawasan Ekonomi Khusus di bitung merupakan sarana pengembangan industrialisasi perikanan. Sasaran strategis industrialisasi perikanan mencakup 3 hal pokok yaitu:

a) Mengembangkan sentra produksi di wilayah pontensial di kawasan PPS Bitung, dan b) Membangun industri pengolahan di sentra produksi dalam satu kesatuan pengembangan;

b. Pengembangan sistem produksi, meliputi a) Meningkatkan produksi komoditas pilihan utama untuk bahan baku industri dan kebutuhan pangan dalam negeri, dan b) Meningkatkan mutu dan kualitas produk serta menjaga kontinuitas produksi; c. Peningkatan sarana dan prasarana, melalui a) Meningkatkan saran dan prasarana pengolahan dan pemasaran serta promosi, dan b) Meningkatkan sarana dan prasarana pendukung produksi perikanan termasuk pengembangan jalan produksi, angkutan dan jalur distribusi.

\section{Peningkatan kualitas SDM nelayan untuk mela- kukan kegiatan penangkapan ikan}

Strategi ini dimaksudkan untuk mengembangkan SDM nelayan melalui ketrampilan dan keahlian khusus di bidang penangkapan ikan. Akibat tingkat pendidikan nelayan yang minim, sehingga adopsi inovasi penangkapan ikan kurang dapat diserap salah satunya dengan adanya teknologi lampu celup dalam untuk mengumpulkan ikan yang hingga saat ini belum dipakai oleh nelayan di PPS Bitung. Selain itu daya tahan nelayan di laut belum optimal bila dibandingkjan dengan nelayan Pilipina. Adapun kualitas nelayan mempengaruhi kualitas hasil tangkapan yang menjadi komoditas unggulan Kota Bitung dengan memanfaatkan pelabuhan laut sebagai sarana tranportasi bagi pemasaran hasil perikanan secara lokal maupun ekspor. Strategi ini untuk mendukung efektifnya operasi penangkapan ikan dan mutu hasil tangkapan dimana akan berdampak pada harga yang menjadi kompetitif dan merupakan bagian komponen transportasi dan distribusi dalam sistem logistik ikan.

\section{Pengembangan perikanan tangkap berkelanjutan}

Konsep perikanan tangkap berkelanjutan tidak semata-mata menyangkut produksi lestari (sustainable yield), potensi perikanan lestari (maximum sustainable yield) dan total allowable catch (TAC). Konsep tersebut masih terfokus untuk menentukan kelestarian output, yaitu produksi ikan yang mengacu pada nilai MSY ataupun TAC. Oleh karena itu, diperlukan perubahan mindset tentang perspektif baru keberlanjutan perikanan tangkap yaitu keberlanjutan proses yang memperhatikan status ekosistem dan manusia. Menurut Charles (2001), perspektif baru tentang konsepsi perikanan berkelanjutan mencakup dua hal pokok, yaitu pertama, kesehatan ekosistem dan sistem manusia (healthy ecosystems and human systems), dan kedua, multiple objectives yakni suatu keseimbangan antara konservasi sumberdaya dan kepentingan manusia.

Komponen-komponen keberlanjutan perikanan mencakup keberlanjutan ekologi, keberlanjutan sosial ekonomi, keberlanjutan masyarakat, serta keberlanjutan kelembagaan. Keberlanjutan ekologi merupakan upaya untuk memelihara keberlanjutan stok atau biomas sehingga tidak melewati daya dukungnya, serta memberikan perhatian utama untuk meningkatkan kapasitas dan kualitas ekosistem. Keberlanjutan sosial ekonomi berarti secara ekonomi pemanfaatan sumberdaya perikanan harus relevan dan secara sosial memberikanan manfaat yang berkelanjutan bagi generasi mendatang. Keberlanjutan komunitas (masyarakat) adalah keterpaduan keberlanjutan kesejahteraan dari sisi komunitas baik kesejahteraan ekonomi maupun sosial budaya serta kesehatan jangka panjang. Keberlanjutan kelembagaan terkait dengan pengelolaan dan pemeliharaan aspek finansial, administrasi yang baik dan sehat serta kemampuan pengorganisasian untuk jangka panjang.

\section{Pengembangan pola kemitraan antara nelayan, pengusaha dan eksportir yang berimbang (win-win partnerships)}

Strategi ini dapat dilakukan melalui integrasi vertikal karena dengan integrasi vertikal dapat dicapai efisiensi yang lebih tinggi. Integrasi vertikal dapat dilakukan melalui pola kemitraan inti plasma maupun contrac farming. Pola kemitraan yang ada sekarang sudah cukup baik tetapi diperlukan penyempurnaan tentang mekanisme 
untuk menyeimbangkan posisi tawar antar nelayan, pedagang pengumpul dan perusahaan. Mengacu pendapat Saptana et al. (2003), kemitraan yang dibangun dapat berjalan dengan seimbang ketika terjadi konsolidasi baik dari anggota rantai pasok maupun manajemen rantai pasoknya. Oleh karena itu yang terpenting dalam pengembangan kelembagaan di tingkat nelayan bukan struktur formalnya tetapi kompatibilitas fungsi-fungsi yang harus dijalankan. Dengan demikian yang perlu memperoleh perhatian serius adalah mengidentifikasi secara seksama kelembagaan lokal yang dapat dijadikan embrio kelembagaan dalam kerangka kemitraan usaha. Pengembangan kelembagaan nelayan harus dilakukan melalui proses sosial yang matang, terencana, tersosialisasikan, yang akhirnya dapat berjalan dengan baik.

Dalam mengembangkan pola kemitraan agribisnis perikanan yang seimbang tentunya memerlukan inovasi kelembagaan dan intervensi. Intervensi seharusnya tidak diartikan sebagai campur tangan akan tetapi hendaknya dipandang sebagai uluran tangan. Setiap tindakan uluran tangan harus mampu menimbulkan perubahan positif, sehingga tindakan perubahan atau pengembangan dapat dirasakan oleh seluruh jaringan agribisnis perikanan atau anggota rantai pasok. Saptana et al. (2003) menjelaskan tentang konsep strategi inovasi kelembagaan, yaitu business intermediary, dan paralel organization. Kelembagaan business intermediary ini sebagai penghantar kelompok nelayan untuk meningkatkan posisi tawarnya pada posisi yang mandiri sejalan dengan tingkat kematangan usaha (business maturity) dan kemitraan usaha yang telah ada. Sementara itu, paralel organization menjadi pendamping yang bersifat fasilitasi, mediasi dan regulatif dalam menghantar business intermediary menjadi lembaga formal yang mandiri, misalnya menjadi koperasi agribisnis perikanan. Strategi ini dilakukan dengan menggunakan beberapa kekuatan internal sistem minapolitan di Bitung untuk mengatasi beberapa ancaman eksternal.

\section{Peningkatan kualitas produk perikanan untuk dapat berdaya saing di pasar bebas}

Strategi ini dimaksudkan agar produksi perikanan tidak hanya meningkat secara kuantitas tetapi juga kualitas. Dengan adanya aglomerasi perekonomian regional dan global dapat menjadi hambatan untuk pemasaran produk-produk perikanan dari Bitung. Bila PPS Bitung bahkan Kota Bitung pada umumnya mampu mengantisipasi aglomerasi perekonomian ini dengan baik, maka akan memperoleh beberapa manfaat berikut yaitu (i)
Produk-produk perikanan akan memiliki peluang pasar yang semakin besar dan luas, (ii) Biaya produksi industri perikanan yang semakin rendah dan pasti bagi pengusaha/produsen Indonesia yang sebelumnya membutuhkan barang modal dan bahan baku/penolong dari negara-negara anggota AFTA dan APEC ASEAN lainnya dan termasuk biaya pemasaran, (iii) Pilihan konsumen atas jenis/ragam produk yang tersedia di pasar domestik semakin banyak dengan tingkat harga dan mutu tertentu, dan (iv) Kerjasama dalam menjalankan bisnis terpadu semakin terbuka dengan beraliansi dengan pelaku bisnis di negara-negara anggota lainnya. Namun, bila tidak diantisipasi aglomerasi perekonomian ini dengan baik, maka akan menjadi ancaman bagi keberlangsungan dan pertumbuhan industri perikanan, termasuk di dalamnya penggunaan tenaga-tenaga kerja lokal. Selain itu, dalam jangka panjang juga akan mengganggu ketahanan nasional, karena Indonesia menjadi tergantung dengan produk-produk perikanan negara lain.

\section{Membangun kesadaran kolektif kerjasama antar lembaga untuk tetap komitmen dan konsisten dalam mengembangkan minapolitan}

Strategi ini dapat dilakukan melalui Forum Lintas Pelaku Minapolitan, public campaign, sosialisasi, dan promosi untuk menyatukan berbagai pihak. Artinya, bentuk-bentuk kegiatan yang dilakukan berupa pertemuan koordinasi, sosialisasi dan konsolidasi terhadap rencana aksi minapolitan, industrialisasi perikanan maupun kemitraan bisnis kepada para pelaku ekonomi atau stakeholders kunci. Hasil yang diharapkan dari strategi ini adalah terumuskannya pola kerja sama pelaksanaan pengembangan atau penguatan industri perikanan yang terintegrasi dalam sistem minapolitan. Kerjasama antar lembaga diperlukan untuk membangun sarana dan prasarana melalui programprogram yang ada di lembaga yang terkait dengan program pengembangan minapolitan di Bitung.

\section{Strategi penambahan jumlah SDM aparatur pelabuhan untuk pengendalian IUU fishing}

Strategi ini dimaksudkan sebagai salah satu tindakan pengendalian IUU Fishing sebelum kapal beroperasi. Terjadinya IUU Fishing dapat dikendalikan melalui keberadaan syahbandar di pelabuhan perikanan, selain bertanggung jawab dalam mengeluarkan administrasi persuratan bagi kapal penangkap dan pengangkut ikan, juga berperan dalam menjaga keselamatan pelayaran serta melaksanakan ketentuan yang terkait dengan pengelolaan perikanan yang bertanggung jawab. Dengan demikian, Syahbandar Pelabuhan Perikanan 
secara tidak langsung juga mempunyai peran penting dalam mencegah dan memerangi/ menanggulangi IUU Fishing.

\section{Prioritas Strategi Pengembangan}

Penetapan prioritas strategi pengembangan minapolitan di Kota Bitung dilakukan menggunakan Analisis QSPM. Urutan strategi prioritas pengembangan kawasan melalui pendekatan minapolitan di Kota Bitung sebagai berikut:

1. Optimalisasi produksi perikanan.

2. Meningkatkan sarana, prasarana dan infrastruktur transportasi dan pelabuhan.

3. Peningkatan kualitas SDM nelayan untuk melakukan penangkapan ikan.

4. Peningkatan kualitas produk perikanan untuk dapat berdaya saing dipasar bebas.

5. Membangun kesadaran kolektif tetap komitmen dan konsisten dalam mengembangkan minapolitan.

6. Industrialisasi perikanan dengan mensuport KEK.

\section{KESIMPULAN}

1. Strategi pengembangan, yaitu: 1) optimalisasi produksi ikan; 2) meningkatkan sarana, prasarana, dan infrastruk-tur transportasi dan pelabuhan perikanan; 3) kerjasama kemitraan bisnis minapolitan; 4) peningkatan kinerja pengelola pelabuhan perikanan; 5) industrialisasi perikanan dengan mensuport KEK; 6) peningkatan kualitas SDM nelayan untuk melakukan kegiatan penangkapan ikan; 7) pengembangan perikanan tangkap berkelanjutan; 8) pengembangan pola kemitraan antara nelayan, pengusaha dan eksportir yang berimbang (winwin partnerships); 9) peningkatan kualitas produk perikanan untuk dapat berdaya saing di pasar bebas; 10) membangun kesadaran kolektif kerjasama antar lembaga untuk tetap komitmen dan konsisten dalam mengembangkan minapolitan; dan 11) penambahan jumlah SDM aparatur pelabuhan untuk pengendalian IUU fishing.

2. Prioritas strategi yang menjadi pilihan utama dalam pengembangan minapolitan di Kota Bitung adalah: 1) optimalisasi produksi ikan; 2) meningkatkan sarana, prasarana, dan infrastruktur transportasi dan pelabuhan perikanan; 3) peningkatan kualitas SDM nelayan untuk melakukan penangkapan ikan; 4) peningkatan kualitas produk perikanan untuk dapat berdaya saing dipasar bebas; 5) membangun kesadaran kolektif tetap komitmen dan konsisten dalam mengembangkan minapolitan; 6) industrialisasi perikanan dengan mensuport KEK.

\section{REFERENSI}

CHARLES, A. (2001) Sustainable Fishery System. Oxford: Blackwell Science Ltd.

KEPMEN (2010) Menteri Kelautan dan Perikanan Republik Indonesia Nomor KEP.32/MEN/ 2010 tentang penetapan kawasan minapolitan.

KKP (2011) Pedoman Umum Minapolitan. Jakarta: Kementerian Kelautan dan Perikanan.

RANGKUTI, F. (2008) Analisis SWOT Teknik Membedah Kasus Bisnis. Jakarta: Penerbit Gramedia Pustaka Umar.

SAPTANA, SUSMONO, SUWARTO, and NUR, M. (2003) Kinerja kelembagaan agribisnis beras di Jawa Barat. Seminar Penyusunan profil investasi dan pengembangan agribisnis beras di Jawa Barat. Bandung: Dinas pertanian Propinsi Jawa Barat.

SKEP BITUNG (2010) Surat Keputusan Walikota Bitung Nomor: 130, Tahun 2010.

Received: 5 December 2017 Accepted: 15 March 2018 